\title{
Anion- $\pi$ interaction in metal-organic networks formed by metal halides and tetracyanopyrazine
}

\author{
Sergiy V. Rosokha, ${ }^{* a}$ Amar Kumar ${ }^{b}$ \\ a) Department of Chemistry, Ball State University, Muncie, IN, USA, 47306 \\ b) Department of Biological, Chemical and Physical Sciences, Roosevelt University, \\ 430 S. Michigan Ave, Chicago, IL, 60605, USA
}

\begin{abstract}
Co-crystallization of tetracyanopyrazine, TCP, with the tetraalkylammonium salts of linear $\left[\mathrm{CuBr}_{2}\right]^{-}$, planar $\left[\mathrm{PtCl}_{4}\right]^{2-}$ or $\left[\mathrm{Pt}_{2} \mathrm{Br}_{6}\right]^{2-}$, or octahedral $\left[\mathrm{PtBr}_{6}\right]^{2-}$ complexes resulted in formation of the alternating $\left[\mathrm{M}_{1} \mathrm{X}_{\mathrm{n}}\right]^{\mathrm{m}-} / \mathrm{TCP}$ stacks separated by the $\mathrm{Alk}_{4} \mathrm{~N}^{+}$cations. These hybrid stacks showed multiple short contacts between halide ligands of the $\left[\mathrm{M}_{1} \mathrm{X}_{\mathrm{n}}\right]^{\mathrm{m}-}$ complexes and carbon atoms of the TCP acceptor indicating strong anion- $\pi$ bonding between these species. It confirmed that the anion- $\pi$ interaction is sufficiently strong to bring together such disparate components as ionic metal complexes and neutral aromatic molecules regardless of the geometry of the coordination compound. Structural features of the solid-state stacks and $\left[\mathrm{M}_{1} \mathrm{X}_{\mathrm{n}}\right]^{\mathrm{m}-\mathrm{TCP}}$ dyads resulted from the quantum-mechanical computations suggests that the molecular-orbital (weakly-covalent) component play an important role in association of the $\left[\mathrm{M}_{1} \mathrm{X}_{\mathrm{n}}\right]^{\mathrm{m}-\mathrm{e}}$ complexes with the TCP acceptor.
\end{abstract}

\footnotetext{
* Corresponding author, e-mail: svrosokha@bsu.edu
} 


\section{Graphical abstract:}
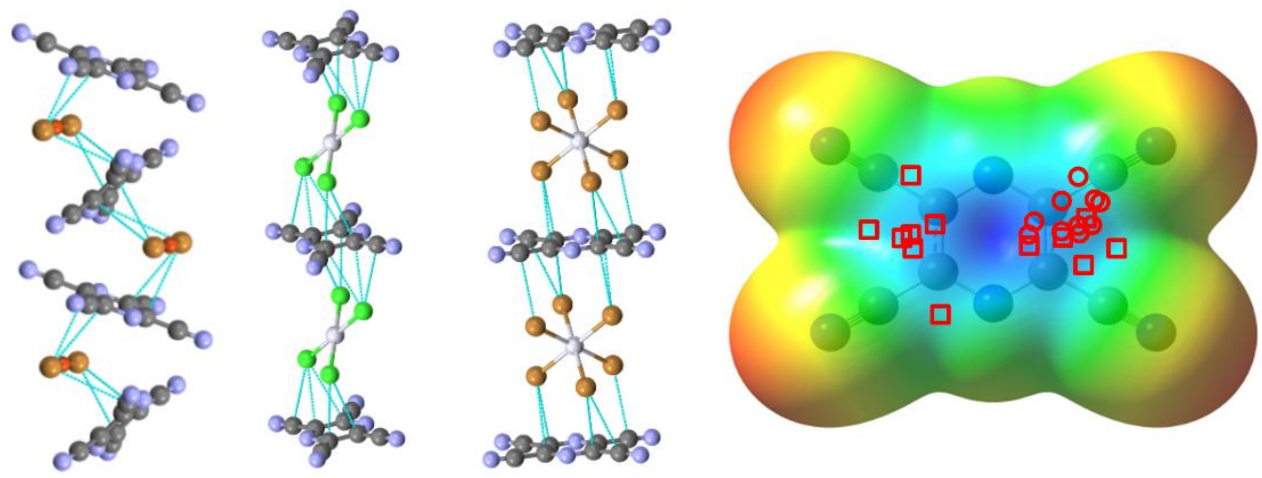

Keywords: Anion- $\pi$ interactions; metal complexes; anion geometry; charge transfer.

Acknowledgement: This work was supported by the National Science Foundation (Grants CHE1112126 and CHE-1607746) and R. A. Welch Foundation. 


\section{Introduction}

Although an attraction between electron-rich species and $\pi$-systems seems counterintuitive, several theoretical studies in the early $2000^{\text {th }}$ demonstrated that such an interaction might be energetically favorable, especially if it involves $\pi$-acidic aromatic rings.[1] Following the pioneering computational works, a number of anion- $\pi$ bonded associates were experimentally characterized in the solid state and in solutions, and examples of such interactions were identified in biological systems.[2-8] Furthermore, several publications demonstrated that this supramolecular interaction can be utilized for preparation of the materials combining organic molecules and transition metal complexes.[9-13] Since coordination of cations enhances $\pi$ acceptor strength, majority of the hybrid anion- $\pi$ bonded systems involve metal ions coordinated to the aromatic molecules (e.g. pyridine).[13] Also, a number of the reported X-ray structures show short contacts between anionic metal complexes and the aromatic systems representing parts of the cationic counter-ion moieties (e.g., $\left[\mathrm{CuCl}_{4}\right]^{2-}$ positioned over the triazine ring of the cationic copper(II)-triazine complex provided one of the first experimental confirmations of anion- $\pi$ bonding).[3,12] In comparison, the data on the association of anionic transition metal complexes with the neutral $\pi$-acceptors are scarce.[10,11,13]

The successful development of the hybrid anion- $\pi$-bonded systems combining anionic metal complexes with neutral organic acceptors requires evaluation of the role of stereochemistry of the coordination compounds in such interaction. However, experimental studies of the effects of geometries of anionic counter-parts in this interaction, were focused on the metal-free anions (such as $\mathrm{NCS}^{-} \mathrm{NO}_{3}^{-}, \mathrm{BF}_{4}^{-}, \mathrm{PF}_{6}^{-}$).[14] While the geometric and energetic features of the anion- $\pi$ complexes involving anionic metal complexes of variable shapes and charges were evaluated 
theoretically,[15] the experimental preparation and structural characterization of the $\pi$-bonded associates comprising neutral $\pi$-acceptors and metal halides were restricted mostly to tetrahedral and square-antiprismatic complexes.[10,11] Thus, to explore the modes of anion- $\pi$ bonding involving linear, planar and octahedral coordination compounds, we report in the current work preparation and structural characterization of the anion- $\pi$ bonded associates involving neutral tetracyanopyrazine acceptor (TCP) and a variety of halometallate anions illustrated in Scheme 1. Structural features of these associates as well as their quantum-mechanical computations shed light on the role of the geometry of coordination sphere of metal complexes in anion- $\pi$ bonding, as well as on the nature of this interaction.<smiles>N#Cc1nc(C#N)c(C#N)nc1C#N</smiles>

TCP

$$
\mathrm{Br}-\mathrm{Cu}^{\prime}-\mathrm{Br}
$$

$\left[\mathrm{CuBr}_{2}\right]^{-}$

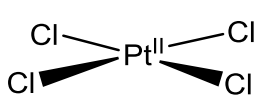

$\left[\mathrm{PtCl}_{4}\right]^{2-}$

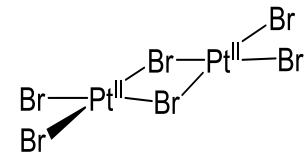

$\left[\mathrm{Prt}_{2} \mathrm{Br}_{6}\right]^{2-}$

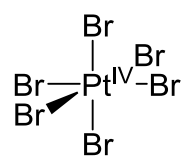

$\left[\mathrm{PtBr}_{6}\right]^{2-}$

Scheme 1. TCP acceptor and $\left[\mathrm{M}_{1} \mathrm{X}_{\mathrm{n}}\right]^{\mathrm{m}-}$ metal complexes.

\section{Results and Discussion}

\subsection{Preparation and $X$-ray structural characterization of the $\left(A l k_{4} N\right)_{m}\left[M_{l} X_{n}\right] \cdot T C P$ co-crystals.}

X-ray structural analyses revealed that crystalline materials precipitated by the diffusion of hexane into the dichloromethane solutions containing tetracyanopyrazine and tetrapropyl- or tetrabutylammonium salt of the metal complexes from Chart 1 comprise both organic acceptor and halometallates in 1:1 molar ratio. Regardless of the geometry of the metal complexes, all these co-crystals show stacks formed by the alternating TCP and $\left[\mathrm{M}_{1} \mathrm{X}_{\mathrm{n}}\right]^{\mathrm{m}-}$ moieties and separated by the alkylammonium counter-ions, as follows.

Co-crystals of TCP with linear halometallates. Co-crystallization of the TCP acceptor with tetrapropylammonium dibromocuprate(I) resulted in formation of pale yellow plates. They are 
characterized by the monoclinic unit cell (space group $\mathrm{P} 21 / \mathrm{n}$ ) and comprise columns formed by the TCP and $\left[\mathrm{CuBr}_{2}\right]^{-}$moieties which propagate along $\mathrm{b}$ axes (Figure 1A). These alternating stacks are separated by tetrapropylammonium cations.

A

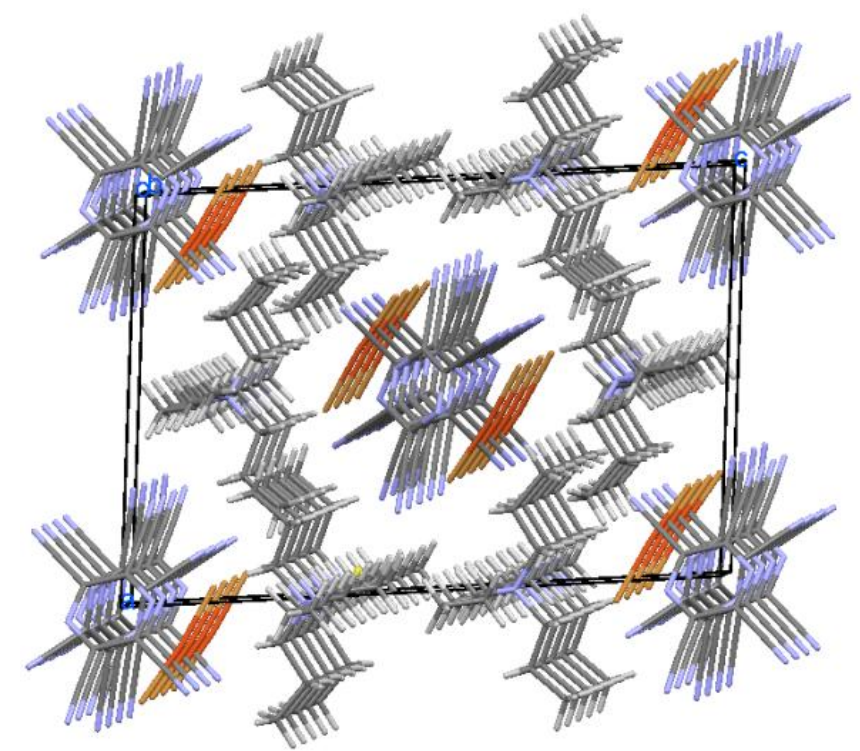

B

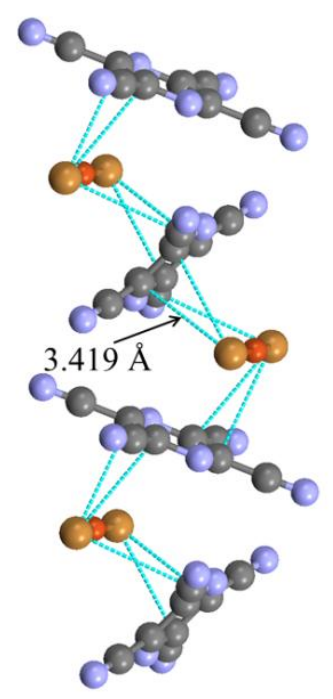

Figure 1. X-ray structure of the co-crystals of TCP acceptor with $\left(\mathrm{Pr}_{4} \mathrm{~N}\right)\left[\mathrm{CuBr}_{2}\right]$ salts showing A) $\mathrm{TCP} /\left[\mathrm{CuBr}_{2}\right]^{-}$stacks separated by the tetrapropylammonium cations. B) Intermolecular contacts shorter than the sum of van der Waals radii (shown as the light blue lines) between the TCP acceptor and the linear $\left[\mathrm{CuBr}_{2}\right]^{-}$complex (the number indicates the shortest contact).

Within the 1D-colums, almost linear dibromocuprate(I) complexes (Br-Cu-Br angle or 174 deg) are nested between tetracyanopyrazine molecules (Figure 1B). The angle between the planes of the neighboring TCP moieties is $67.7 \mathrm{deg}$, and the every other tetracyanopyrazine (i.e. all odd numbered or all even numbered species) are parallel. The $\mathrm{CuBr}_{2}{ }^{-}$complex is nearly parallel to the planes of both its neighbors, so that the distances between bromide anions and the plane of one of the adjacent TCP are $3.276 \AA$ and $3.293 \AA$, and distance to the plane of another neighbor are $3.274 \AA$ and $3.372 \AA$. Also, there are several short contacts between the bromide ligands of $\mathrm{CuBr}_{2}{ }^{-}$complexes and the carbon atoms of both adjacent TCP acceptors (Figure 1B, Table 1).[16] 
Table 1. Short intermolecular contacts between TCP acceptor and $\left[\mathrm{M}_{1} \mathrm{X}_{\mathrm{n}}\right]^{\mathrm{m}-}$ complexes. $^{\mathrm{a}}$

\begin{tabular}{|c|c|c|}
\hline Co-crystal & Contact $^{\mathrm{b}}$ & $\mathrm{d}, \AA$ \\
\hline \multirow[t]{5}{*}{$\left(\mathrm{Pr}_{4} \mathrm{~N}\right)\left[\mathrm{CuBr}_{2}\right] \cdot \mathrm{TCP}$} & $\mathrm{Br} 1 \cdots \mathrm{C} 2^{\mathrm{i}}$ & $3.440(4)$ \\
\hline & $\operatorname{Br} 1 \cdots C 3^{i}$ & $3.426(3)$ \\
\hline & $\mathrm{Br} 1 \cdots \mathrm{C} 5$ & $3.535(3)$ \\
\hline & $\mathrm{Br} 2 \cdots \mathrm{C} 6$ & $3.440(3$ \\
\hline & $\mathrm{Br} 2 \cdots \mathrm{C}^{\mathrm{i}}$ & $3.419(3)$ \\
\hline \multirow[t]{5}{*}{$\left(\mathrm{Pr}_{4} \mathrm{~N}\right)_{2}\left[\mathrm{PtCl}_{4}\right] \cdot \mathrm{TCP}$} & 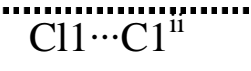 & $3.318(3)$ \\
\hline & $\mathrm{Cl} 1 \cdots \mathrm{C} 22^{\mathrm{ii}}$ & $3.218(3)$ \\
\hline & $\mathrm{Cl} 1 \cdots \mathrm{C} 3^{\text {iii }}$ & $3.358(2)$ \\
\hline & $\mathrm{Cl} 2 \cdots \mathrm{C} 2^{\text {iv }}$ & $3.283(3)$ \\
\hline & $\mathrm{Cl} 2 \cdots \mathrm{C} 33^{\mathrm{iii}}$ & $3.222(3)$ \\
\hline \multirow[t]{5}{*}{$\left(\mathrm{Bu}_{4} \mathrm{~N}\right)_{2}\left[\mathrm{Pt}_{2} \mathrm{Br}_{6}\right] \cdot \mathrm{TCP} \cdot 2 \mathrm{CH}_{2} \mathrm{Cl}_{2}$} & $\mathrm{Br} 3 \cdots \mathrm{C} 18$ & $3.380(17)$ \\
\hline & $\mathrm{Br} 3 \cdots \mathrm{C} 19$ & $3.496(16)$ \\
\hline & $\mathrm{Br} 1 \cdots \mathrm{C} 17^{\mathrm{vii}}$ & $3.438(16)$ \\
\hline & $\mathrm{Br} 1 \cdots \mathrm{C} 18^{\mathrm{vii}}$ & $3.547(15)$ \\
\hline & $\mathrm{Br} 1 \cdots \mathrm{C} 20^{\mathrm{vii}}$ & $3.440(18)$ \\
\hline \multirow[t]{10}{*}{$\left(\mathrm{Bu}_{4} \mathrm{~N}\right)_{2}\left[\mathrm{PtBr}_{6}\right] \cdot \mathrm{TCP}$} & $\mathrm{Br} 5 \cdots \mathrm{C} 8$ & $3.516(15)$ \\
\hline & Br5 $\cdots C 7$ & $3.536(12)$ \\
\hline & $\mathrm{Br} 6 \cdots \mathrm{C} 7^{\mathrm{iv}}$ & $3.368(12)$ \\
\hline & Br6 ‥C6 & $3.500(11)$ \\
\hline & $\mathrm{Br} 4 \cdots \mathrm{C} 5^{\mathrm{v}}$ & $3.483(15)$ \\
\hline & $\mathrm{Br} 2 \cdots \mathrm{C} 1^{\mathrm{vi}}$ & $3.481(13)$ \\
\hline & $\mathrm{Br} 2 \cdots \mathrm{C} 22^{\mathrm{vi}}$ & $3.294(11)$ \\
\hline & $\mathrm{Br} 2 \cdots \mathrm{C} 3^{\text {vi }}$ & $3.502(12)$ \\
\hline & $\mathrm{Br} 3 \cdots \mathrm{C} 2$ & $3.357(12)$ \\
\hline & $\mathrm{Br} 3 \cdots \mathrm{C} 1$ & $3.431(12)$ \\
\hline
\end{tabular}

$\left(\mathrm{Pr}_{4} \mathrm{~N}\right)_{2}\left[\mathrm{PtBr}_{6}\right] \cdot \mathrm{TCP} \cdot 2 \mathrm{CH}_{2} \mathrm{Cl}_{2} \quad \mathrm{Br} 1 \cdots \mathrm{C} 20 \quad 3.513(4)$

a) See numbering of the contact atoms in Figures S1 - S5 in the Supporting Information. b) The sums of the van der Waals radii are $3.55 \AA$ for $\mathrm{C} / \mathrm{Br}$ pair and $3.45 \AA$ for $\mathrm{C} / \mathrm{Cl}$ pair.[16] Symmetry codes i) -x, 1-y, -z; ii) $1-\mathrm{x},-\mathrm{y}, 1-\mathrm{z}$; iii) $\mathrm{x}, \mathrm{y},-1+\mathrm{z}$; iv) $2-\mathrm{x},-\mathrm{y}, 1-\mathrm{z}$; v) $-1+\mathrm{x}, \mathrm{y}, \mathrm{z}$; vi) $1+\mathrm{x}, \mathrm{y}, \mathrm{z}$; vii) $\mathrm{x},-1+\mathrm{y}, \mathrm{z}$; viii) $1-\mathrm{x},-\mathrm{y},-\mathrm{z}$. 
Co-crystals of TCP with planar halometallates. Co-crystallization of TCP acceptor with $\left(\mathrm{Pr}_{4} \mathrm{~N}\right)_{2}\left[\mathrm{PtCl}_{4}\right]$ salt resulted in formation of dark red crystals (monoclinic unit cell, space group $\left.\mathrm{P} 2_{1} / \mathrm{c}\right)$. They show stacks formed by the neutral tetracyanopyrazine molecules and the $\left[\mathrm{PtCl}_{4}\right]^{2-}$ dianions which propagate along a-axes (Figure S6 in the Supporting Information). Within these stacks (separated by the alkylammonium counter-ions), parallel tetracyanopyrazine moieties alternate with the square-planar $\left[\mathrm{PtCl}_{4}\right]^{2-}$ complexes. The angle between the planes of TCP and tetrachloroplatinate(II) is $49.7 \mathrm{deg}$ (Figure 2A).

A

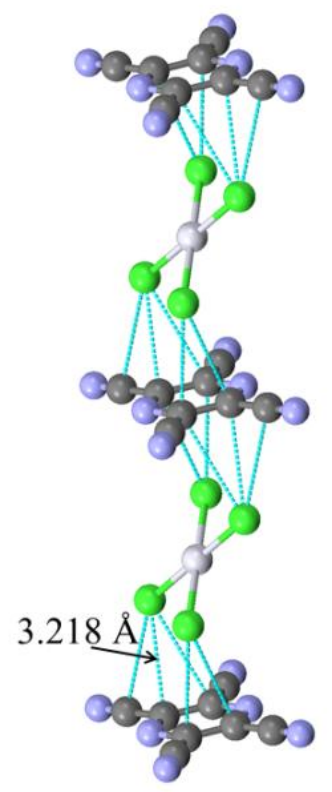

B

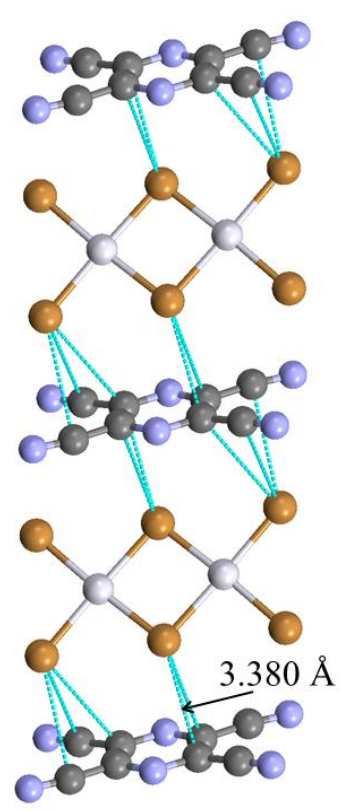

Figure 2. $\left[\mathrm{M}_{1} \mathrm{X}_{\mathrm{n}}\right]^{\mathrm{m}-} / \mathrm{TCP}$ stacks in the $\left(\mathrm{Pr}_{4} \mathrm{~N}\right)_{2}\left[\mathrm{PtCl}_{4}\right] \cdot \mathrm{TCP}(\mathrm{A})$ and $\left(\mathrm{Bu}_{4} \mathrm{~N}\right)_{2}\left[\mathrm{Pt}_{2} \mathrm{Br}_{6}\right] \cdot \mathrm{TCP}(\mathrm{B})$ co-crystals. Light dotted lines indicate contacts shorter than sum of the van der Waals radii (numbers indicate shortest contacts in each structure).

One pair of chloride ligands of each platinum ion (which is located at the inversion centers) form short contacts with five carbon atoms of one of the neighboring TCP moieties, and another pair of chloride ligands show analogous contacts with the tetracyanopyrazine located on the opposite side of the platinum complex. These $\mathrm{Cl} \cdots \mathrm{C}$ separations are about $0.2 \AA$ shorter than the sum of the corresponding van der Waals radii (Table 1). 
In a similar way, the triclinic co-crystals formed by the tetracyanopyrazine acceptor and $\left(\mathrm{Bu}_{4} \mathrm{~N}\right)_{2}\left[\mathrm{Pt}_{2} \mathrm{Br}_{6}\right]$ salt comprise stacks in which TCP moieties alternate with the planar $\mathrm{Pt}_{2} \mathrm{Br}_{6}{ }^{2-}$ dianions. The angle between the planes of tetracyanopyrazine and $\left[\mathrm{Pt}_{2} \mathrm{Br}_{6}\right]^{2-}$ dianion is $56.1 \mathrm{deg}$ (Figure 2B). In this case, the inversion centers are located at the midpoint between two platinum ions bridged by pairs of bromides. As such, the bridging and terminal bromine ligands of one $\mathrm{Pt}(\mathrm{II})$ ion form short contacts with the carbon atoms of the tetracyanopyrazine on one side of the complex. The terminal and bridging ligand of another $\mathrm{Pt}(\mathrm{II})$ ion form contacts with the pair of bromide ligand on the other side of the $\left[\mathrm{Pt}_{2} \mathrm{Br}_{6}\right]^{2-}$ complex (Figure 2B). These intermolecular distances are listed in Table 1.

Co-crystals of TCP with octahedral halometallates. Tetrabutyl- and tetrapropylammonium salts of octahedral hexabromoplatinate(IV) also formed co-crystals with tetracyanopyrazine which show alternating stacks formed by TCP $\pi$-acceptors and $\left[\mathrm{PtBr}_{6}\right]^{2-}$ dianions (Figure 3 and Figures S4 and S5 in the Supporting Information). In all these stacks, three bromide ligands
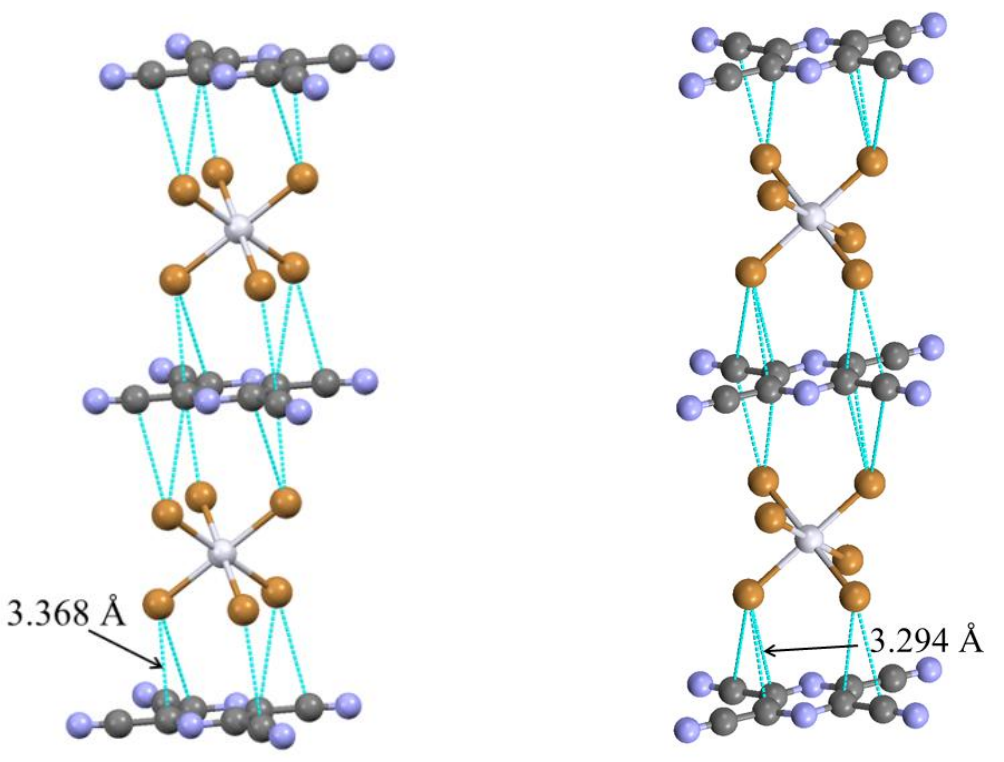

Figure 3. Two crystallographically independent anion- $\pi$ bonded stacks formed by the TCP acceptor with the octahedral $\left[\mathrm{PtBr}_{6}\right]^{2-}$ complex in the $\left(\mathrm{Bu}_{4} \mathrm{~N}\right)_{2}\left[\mathrm{PtBr}_{6}\right] \cdot \mathrm{TCP}$ co-crystals. Light dotted lines indicate intermolecular contacts shorter than sum of the van der Waals radii. 
of each $\mathrm{PtBr}_{6}{ }^{2-}$ complex are generally directed toward one of its TCP neighbor, and remaining three ligands are directed toward the TCP molecule on the opposite side. The distinctions in the relative orientations of neighboring TCP acceptors and $\left[\mathrm{PtBr}_{6}\right]^{2-}$ dianions led to the variations of the number of the contacts between bromide ligands and carbon atoms which are shorter than the sum of the van der Waals radii (Table 1).

Specifically, in the TCP co-crystals with $\left(\mathrm{Bu}_{4} \mathrm{~N}\right)_{2}\left[\mathrm{PtBr}_{6}\right]$ salt, two crystallographically independent TCP molecules form two distinct stacks with hexabromoplatinate dianions (Figure 3). The distances between the bromine ligands of hexabromoplatinate(IV) to the TCP planes are similar in both stacks $(3.24 \AA, 3.32 \AA$ and $3.49 \AA$ in the first and $3.21 \AA, 3.32 \AA$ and $3.33 \AA$ in the second stack). Within the first stack, three bromide ligands form short contacts with the carbon atoms of one TCP neighbor of the hexabromoplatinate. The remaining three bromide ligands of the platinum ion (located at the inversion center) form symmetrical contacts with the acceptor on the opposite side of the $\left[\mathrm{PtBr}_{6}\right]^{2-}$ dianion (Table 1). Due to a small turn of the hexabromoplatinate relative to the TCP molecule in the second stacks, pairs of bromide ligands form short contacts with the adjacent tetracyanopyrazine molecules on both sides of the $\left[\mathrm{PtBr}_{6}\right]^{2-}$ dianion (and the distances from the third bromide ions to the TCP molecules on the both sides of platinum complex are somewhat larger than the sum of the van der Waals radii).

In the $\left(\mathrm{Pr}_{4} \mathrm{~N}\right)_{2}\left[\mathrm{PtBr}_{6}\right] \cdot \mathrm{TCP}$ co-crystal, the distances between bromide ligands of hexabromoplatinate(IV) and the tetracyanopyrazine plane (3.154 $\mathrm{A}, 3.362 \AA$ and $3.522 \AA$ ) are comparable to those measured in the $\left(\mathrm{Bu}_{4} \mathrm{~N}\right)_{2}\left[\mathrm{PtBr}_{6}\right] \cdot \mathrm{TCP}$ structure. However, only one short $\mathrm{Br} . . \mathrm{C}$ contact between $\left[\mathrm{PtBr}_{6}\right]^{2-}$ and each of the (disordered) neighboring TCP molecule can be identified in the $\left(\mathrm{Pr}_{4} \mathrm{~N}\right)_{2}\left[\mathrm{PtBr}_{6}\right] \cdot \mathrm{TCP}$ structure (Table 1, Figure S5 in the Supporting Information). 


\subsection{Computational analysis of the $\left[M_{l} X_{n}\right]^{m-}$ associates with the TCP acceptor(s).}

Geometric features of the experimental anion- $\pi$ associates involving tetracyanopyrazine acceptor accord, in part, with the results of the quantum-mechanical computations of various halometallate complexes with pyrazine reported by Frontera and co-workers.[15] Specifically, their calculations predicted that the most stable associates of octahedral $\left[\mathrm{BiCl}_{6}\right]^{2-}$ and $\left[\mathrm{TeCl}_{6}\right]^{2-}$ complexes with pyrazine are formed via the two- or three-point interactions, and the X-ray structures of the co-crystals of $\left[\mathrm{PtBr}_{6}\right]^{2-}$ complexes with tetracyanopyrazine showed generally similar arrangements of anions and $\pi$-acceptors. Also, essentially the same stacked arrangement was found experimentally for the $\left[\mathrm{CuBr}_{2}\right]^{-}$complexes with TCP and in the most stable calculated complex of the linear $\left[\mathrm{CuCl}_{2}\right]^{-}$anion with pyrazine.

In contrast to the linear and octahedral complexes, anion- $\pi$ bonded associates with planar halometallates showed significant difference between experimental (solid-state) and calculated arrangements of the interacting species. In particular, the earlier computations predicted that the most stable complex formed by the $\left[\mathrm{PtCl}_{4}\right]^{2-}$ complex and pyrazine comprised stacked planar anion and acceptor.[15] In comparison, the co-crystals of tetrachloroplatinate(II) and the TCP molecules showed the inclined orientation of the anion relative to the acceptor plane with the two-point $\left[\mathrm{PtCl}_{4}\right] \cdot \mathrm{TCP}$ interaction. Moreover, similar inclined orientation was found in the solidstate associates of the planar $\left[\mathrm{Pt}_{2} \mathrm{Br}_{6}\right]^{2-}$ dianion with the TCP acceptor. It confirmed that such orientation of the planar complexes is not related to the particular architecture (and crystal forces) of the $\left(\mathrm{Pr}_{4} \mathrm{~N}\right)_{2}\left[\mathrm{PtCl}_{4}\right] \cdot \mathrm{TCP}$ co-crystals.

To check if the differences between calculated and solid-state structures are related to the presence of the strong cyano-substituents in the aromatic $\pi$-acceptor, we carried out M062X /def- 
TZVPP optimization of the $\left[\mathrm{M}_{1} \mathrm{X}_{\mathrm{n}}\right]^{\mathrm{m}-\mathrm{T}} \cdot \mathrm{TCP}$ associates (see Experimental and Computational

Methods for details). The optimized geometries of these dyads are illustrated in Figure 4.

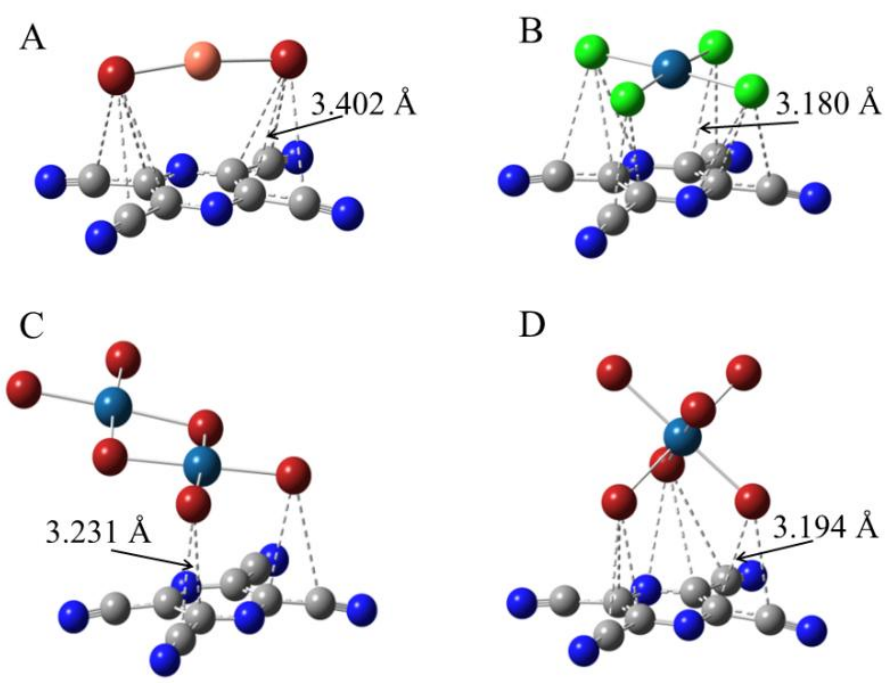

Figure 4. Optimized geometries of anion- $\pi$ complexes formed by TCP acceptor with $\left[\mathrm{CuBr}_{2}\right]^{-}$ (A), $\left[\mathrm{PtCl}_{4}\right]^{2-}(\mathrm{B}), \quad\left[\mathrm{Pt}_{2} \mathrm{Br}_{6}\right]^{2-}(\mathrm{C})$ and $\left[\mathrm{PtBr}_{6}\right]^{2-}(\mathrm{D})$. Light dashed lines represent contacts shorter than the corresponding van der Walls separations (numbers indicate shortest contacts in each structure).

The BSSE-corrected interaction energies and selected short interatomic contacts in the TCP complexes with linear, planar, tetrahedral, and octahedral halometallates resulted from these calculations are listed in Table 2 .

Table 2. Interaction energies, distances and charge-transfer in the $\left[\mathrm{M}_{1} \mathrm{X}_{\mathrm{n}}\right]^{\mathrm{m}-\mathrm{T}} \cdot \mathrm{TCP}$ associates.

\begin{tabular}{cccccc}
{$\left[\mathrm{M}_{1} \mathrm{X}_{\mathrm{n}}\right]^{\mathrm{m}-}$} & Orientation & $\mathrm{E}^{\mathrm{a}}, \mathrm{kcal} / \mathrm{mol}$ & $\mathrm{R}_{\mathrm{Cent} \ldots \mathrm{M}},{ }^{\mathrm{b}} \AA$ & $\mathrm{R}_{\mathrm{X} \ldots \mathrm{C}},{ }^{\mathrm{c}} \AA$ & $\mathrm{q}_{\mathrm{TCP}},{ }^{\mathrm{d}} \overline{\mathrm{e}}$ \\
\hline$\left[\mathrm{CuBr}_{2}\right]^{-}$ & stacked & -22.7942 & 3.282 & 3.402 & -0.062 \\
{$\left[\mathrm{PtCl}_{4}\right]^{2-}$} & stacked & -47.4551 & 3.120 & 3.180 & -0.110 \\
{$\left[\mathrm{Pt}_{2} \mathrm{Br}_{6}\right]^{2-}$} & stacked & -30.6292 & 3.431 & 3.231 & -0.083 \\
{$\left[\mathrm{PtBr}_{6}\right]^{2-}$} & three-point & -36.2773 & 4.589 & 3.194 & -0.123
\end{tabular}

a) BSSE corrected interaction energies from M06-2X/6-311+G(d,p) computations. b) Distances from metal ion to the TCP ring centroid. c) Shortest interatomic $\left[\mathrm{M}_{1} \mathrm{X}_{\mathrm{n}}\right]^{\mathrm{m}} / \mathrm{TCP}$ distances. d) Charge on the TCP acceptor (from the NBO analysis). 
Short distances between metal ions and the aromatic ring centroids of the TCP $\pi$ acceptor, multiple short interatomic contacts and significant interaction energies listed in Table 2 point out the strong anion- $\pi$ bonding in the $\left[\mathrm{M}_{1} \mathrm{X}_{n}\right]^{\mathrm{m}-} \cdot \mathrm{TCP}$ dyads. Similar to the reported earlier complexes with pyrazine,[15] our computations produced stacked associates of TCP molecule with the linear and planar halometallates, and three-point orientation for the octahedral $\left[\mathrm{PtBr}_{6}\right]^{2-}$ dianion. (Note, that there is a small angle of $4.5 \mathrm{deg}$ between the planes TCP acceptor and stacked $\mathrm{PtBr}_{4}$ fragment in the calculated $\left[\mathrm{Pt}_{2} \mathrm{Br}_{6}\right]^{2-} \cdot \mathrm{TCP}$ complex. In contrast to the experimental structure in Figure 2B, this deviation from co-planarity occur perpendicular to the N-N axes in the TCP acceptor and it is probably related to the presence of the non-bonded $\mathrm{PtBr}_{2}$ fragment). Notably, the stacked orientations of the aromatic $\pi$-acceptor and planar halometallates in the calculated $\left[\mathrm{M}_{1} \mathrm{X}_{\mathrm{n}}\right]^{\mathrm{m}-} \cdot \mathrm{TCP}$ dyads contrast to their inclined arrangements in the solid-state associates. Since the latter comprise the infinite donor/acceptor stacks formed by interactions of $\left[\mathrm{PtCl}_{4}\right]^{2-}$ dianions with two TCP molecules (and vice versa), we carried out optimization of the 1:2 associates of tetrachloroplatinate(II) with two tetracyanopyrazines. Such computations also resulted in the stacked parallel arrangement of the interacting species (see Figure S7 in the Supporting Information). Thus, although the effects of the solid-state environments preclude unambiguous comparison of the X-ray structures with the calculated associates, the data obtained in the current work suggest that further studies are required to establish computational method capable of a reliable prediction of the structural features of anion- $\pi$ complexes with planar coordination compounds.

Most importantly, all calculated complexes and (experimental) solid-state associates formed by the TCP molecules and halometallates from Chart 1 show multiple intermolecular $\mathrm{C} \cdots \mathrm{X}$ contacts between aromatic $\pi$-acceptor and $\left[\mathrm{M}_{1} \mathrm{X}_{\mathrm{n}}\right]^{\mathrm{m}-}$ complexes which are shorter than the sum of 
the van der Waals radii of the carbon atom and halide ligand (Tables 1 and 2). Moreover, in the calculated $\left[\mathrm{CuBr}_{2}\right]^{-} \cdot \mathrm{TCP}$ and $\left[\mathrm{PtCl}_{4}\right]^{2-} \cdot \mathrm{TCP}$ complexes, the halide ligands are bended toward TCP acceptor, so the $\mathrm{Br}-\mathrm{Cu}-\mathrm{Br}$ angle is $172 \mathrm{deg}$ and $\mathrm{Cl}-\mathrm{Pt}-\mathrm{Cl}$ angles are about $175 \mathrm{deg}$ (as compared to the $180 \mathrm{deg}$ in the separate halometallates). It confirms that anion- $\pi$ bonding represents a main driving force responsible for the formation of these hybrid networks. While the major role in the anion- $\pi$ bonding is related, in general, to ion-induced polarization and electrostatic attraction of anions to the $\pi$-holes, $[13,17,18]$ a number of experimental and computational studies pointed out the major contribution of charge-transfer (weakly-covalent) component to the formation of the complexes between strong $\pi$-acceptor and many anionic species. $[4,6,19,20]$ Close consideration of the structural features of the $\left[\mathrm{M}_{1} \mathrm{X}_{n}\right]^{\mathrm{m}-} \cdot \mathrm{TCP}$ associates also suggests the significant role of the charge-transfer (weakly-covalent) interactions in the anion- $\pi$ bonding of TCP acceptor with halometallates. In fact, a Natural Bond Orbitals (NBO) analysis of charge distributions in the $\left[\mathrm{M}_{1} \mathrm{X}_{\mathrm{n}}\right]^{\mathrm{m}-}$. TCP dyads show noticeable charge transfer from the halometallate anions to the TCP acceptor (last column in Table 2). These $\mathrm{q}_{\mathrm{TCP}}$ values are comparable to the amount of charge transfer in the classical $\pi$-donor/acceptor complexes.[21] Furthermore, the calculations of the surface electrostatic potential of tetracyanopyrazine revealed that the area of the most positive potential, i.e. a $\pi$-hole, is located near the center of its aromatic ring (Figure 5A). As such, the dominance of the electrostatic attraction in formation of anion- $\pi$ complexes with TCP would likely lead to location of anions over the center of the acceptor. Yet, the reported earlier X-ray structures of TCP complexes with halide anions [4] demonstrated that the latter are positioned over the periphery of TCP (black circles in Figure 5). Apparently, such positions are related to the location of main fragments of the LUMO of TCP acceptor (Figure 5B) allowing efficient HOMO / LUMO interaction (vide infra).[19] 
A

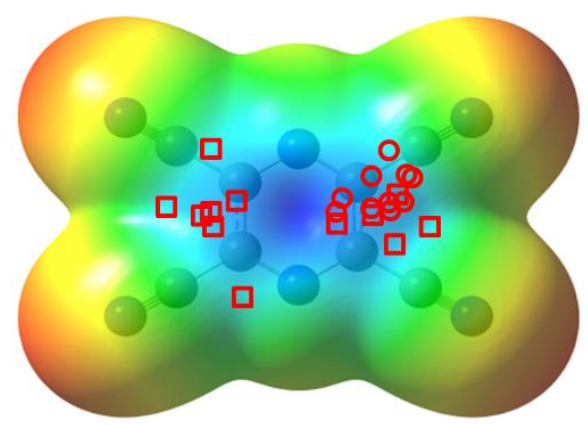

B

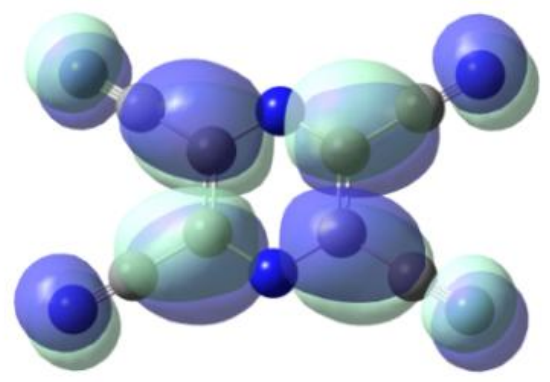

Figure 5. Surface electrostatic potential (A) and LUMO (B) of the TCP acceptor. Red circles and squares indicate locations of halide anions above the TCP plane in the X-ray structures of $\mathrm{X}^{-} \cdot \mathrm{TCP}(\circ)[19]$ and $\left[\mathrm{M}_{1} \mathrm{X}_{\mathrm{n}}\right]^{\mathrm{m}} \cdot \mathrm{TCP}(\square)$.

Based on such structural as well as UV-Vis spectral data, complexes of tetracyanopyrazine with halide anions were classified as charge transfer (or weakly-covalent) donor/acceptor complexes. $[4,6]$ Similar tendency is observed in the anion- $\pi$ complexes between TCP and halometallates. In all complexes considered herein (and in the analogous associates with tetrahedral complexes reported earlier[10]), halide ligands are located over the periphery of the tetracyanopyrazine (squares in Figure 5). Moreover, the superpositions of the frontier orbitals of the electron donors and acceptors onto the crystal structures of their complexes showed that the donor / acceptor arrangements facilitate bonding HOMO/LUMO interactions (as illustrated for $\left[\mathrm{CuBr}_{2}\right]^{-} \cdot \mathrm{TCP}$ dyad in Figure 6).
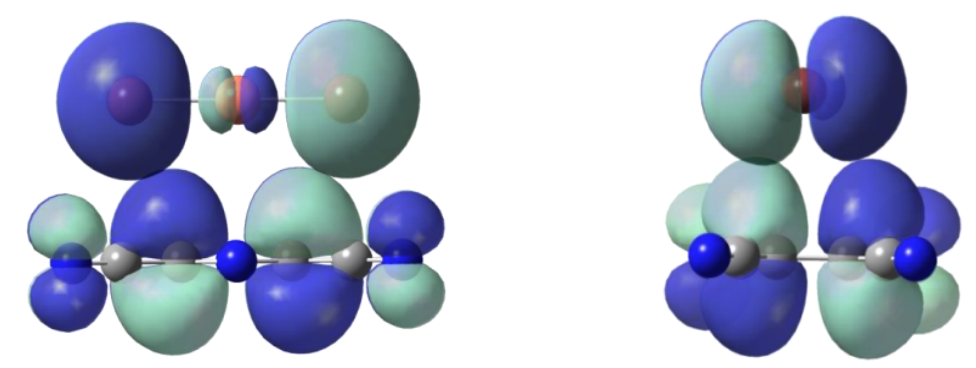

Figure 6. Front (left) and side (right) views of the frontier orbital shapes of $\left.\mathrm{CuBr}_{2}\right]^{-}$(HOMO) and TCP (LUMO) superimposed onto crystal structures of their complexes. 
Interestingly, a qualitative molecular orbital consideration might explain the inclined geometries of the anion- $\pi$ associates of TCP with planar $\left[\mathrm{PtCl}_{4}\right]^{2-}$ (or $\left[\mathrm{Pt}_{2} \mathrm{Br}_{6}\right]^{2-}$ complexes. Specifically, the comparison of the symmetry of LUMO of TCP acceptor (Figure 5B) with that of the pair of degenerated HOMOs of the $\left[\mathrm{PtCl}_{4}\right]^{2-}$ (Figure 7) suggests that only two halide ligands may be involved in the bonding HOMO/LUMO interaction with the TCP acceptor. Due to the

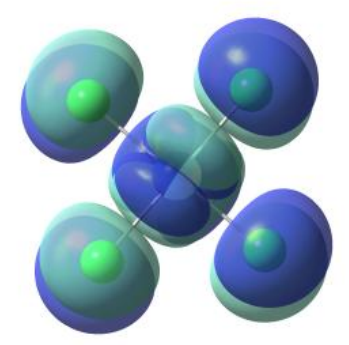

Figure 7. Degenerated HOMOs of the $\left[\mathrm{PtCl}_{4}\right]^{2-}$ donor .

distinctions in the symmetries of the frontier orbitals of donor and acceptor, their parallel or perpendicular arrangements are not suitable for the bonding HOMO/LUMO interaction. In contrast, inclined orientation of the $\left[\mathrm{PtCl}_{4}\right]^{2-}$ and TCP moieties allows bonding interactions of one pair of the bromide ligands with the TCP molecule on one side of the tetrachloroplatinate and another pair of ligands with the TCP neighbor on the opposite side, as illustrated in Figure 8.
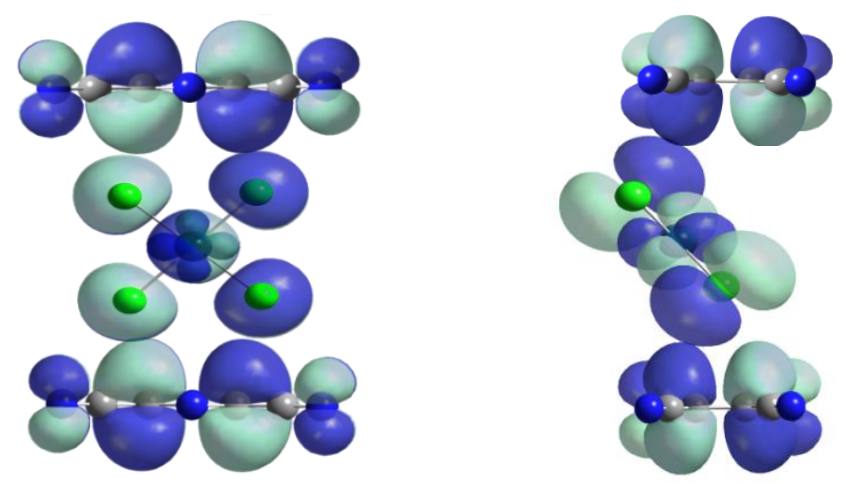

Figure 8. Front (left) and side (right) views of the frontier orbitals of the TCP acceptor and $\left[\mathrm{PtCl}_{4}\right]^{2-}$ dianion superimposed on their 1:2 associate of their complex. 


\section{Conclusions.}

Crystallization and structural analysis of the anion- $\pi$ bonded associates reported in the current work demonstrated that anion- $\pi$ interaction between tetracyanopyrazine and halometallates is sufficiently strong to bring together neutral acceptor and anionic metal complexes regardless of their geometric features. Similar to the reported earlier systems with the tetrahedral halometallates,[10] linear, planar and octahedral metal complexes form alternating 1D-stacks showing close contacts between anionic species and neutral acceptors. Analysis of the geometric features of the TCP/[M $\left.\mathrm{M}_{\mathrm{n}}\right]^{\mathrm{m-}}$ associates suggests important role of molecular orbital interactions in the anion- $\pi$ bonding involving tetracyanopyrazine and halometallates.

\section{Experimental section.}

Materials. Tetrabutyl- and tetrapropylammonium bromides, tetrapropylammonium chloride and copper(I) bromide (from Sigma Aldrich) and tetracyanopyrazine (from DuPont) were used as received. $\left(\mathrm{NPr}_{4}\right)\left[\mathrm{CuBr}_{2}\right]$ salt was prepared from copper(I) bromide and 1 equiv of tetrapropylammonium bromide.[22] $\mathrm{K}_{2}\left[\mathrm{PtBr}_{6}\right]$ was prepared by the dissolution of platinum sponge in 3:1 mixture of hydrobromic and nitric acids, evaporation of the solution to dryness, dissolving of the residue in $\mathrm{HBr}$ and treatment of this solution with $\mathrm{KBr}$. [23] $\mathrm{K}_{2}\left[\mathrm{PtBr}_{4}\right]$ was prepared by the reduction of $\mathrm{K}_{2} \mathrm{PtBr}_{6}$ with hydrazine sulfate. [23] $\left(\mathrm{NBu}_{4}\right)_{2}\left[\mathrm{PtBr}_{6}\right],\left(\mathrm{Pr}_{4} \mathrm{~N}\right)_{2}\left[\mathrm{PtBr}_{6}\right]$, $\left(\mathrm{NBu}_{4}\right)_{2}\left[\mathrm{Pt}_{2} \mathrm{Br}_{6}\right]$ and $\left(\mathrm{Pr}_{4} \mathrm{~N}\right)_{2}\left[\mathrm{PtCl}_{4}\right]$, were prepared by ion-exchange of the corresponding potassium salts of platinum(IV) or platinum(II) with the tetraalkylammonium halides.[24] Crystallization and X-ray crystallography. Anion- $\pi$ bonded associates were crystallized by diffusion of hexane into dichloromethane solutions containing 1:1 mixtures of the TCP acceptor and alkylammonium salt of halometallate at low temperatures $\left(-35^{\circ} \mathrm{C}\right.$ to $\left.-70^{\circ} \mathrm{C}\right)$. Intensity data for $\mathrm{X}$ ray crystallographic analysis were collected at $173 \mathrm{~K}$ with a Bruker SMART Apex diffractometer 
using Mo K $\alpha$ radiation $(\lambda=0.71073 \AA)$. The structures were solved by direct methods and refined by full matrix least-squares treatment.[25] Intermolecular contacts were analyzed using the OLEX2 structure solution, refinement and analysis program. [26] CCDC 1523244-1523248 contain the supplementary crystallographic data for this paper. These data can be obtained free of charge via http://www.ccdc.cam.ac.uk/conts/retrieving.html (or from the Cambridge Crystallographic Data Centre, 12, Union Road, Cambridge CB2 1EZ, UK; fax: +44 1223 336033).

$\left(\mathrm{Pr}_{4}\right)_{2}\left[\mathrm{PtCl}_{4}\right] \cdot \mathrm{TCP} .71 \mathrm{mg}(0.10 \mathrm{mmol})$ and $18 \mathrm{mg}(0.10 \mathrm{mmol})$ of $\left(\mathrm{Pr}_{4} \mathrm{~N}\right)_{2}\left[\mathrm{PtCl}_{4}\right]$ was dissolved in $5 \mathrm{~mL}$ of dichloromethane together with $18 \mathrm{mg}(0.10 \mathrm{mmol})$ of TCP in a $25 \mathrm{~mL}$ Schlenk tube. This solution was carefully layered with $1 \mathrm{~mL}$ of 1:1 dichloromethane/hexane mixture as well as with $\sim 10 \mathrm{ml}$ of hexane, and then it was placed in refrigerator $\left(-30^{\circ} \mathrm{C}\right)$. Slow diffusion of hexane resulted in formation of the dark red blocks. Analysis: Calc. for $\mathrm{C}_{32} \mathrm{H}_{56} \mathrm{Cl}_{4}$ $\mathrm{N}_{8} \mathrm{Pt}, \%: \mathrm{C}, 43.20 ; \mathrm{H}, 6.34 ; \mathrm{N}, 12.59$. Found, \%: C, 43.16; H, 6.38; N, 12.51. Crystal data: $\mathrm{C}_{32}$ $\mathrm{H}_{56} \mathrm{Cl}_{4} \mathrm{~N}_{8}$ Pt. $\mathrm{M}=889.74$, monoclinic, $a=8.9792(13) \AA, \quad b=15.046(2) \AA, c=14.849(2) \AA, \beta=$ $102.880(3)^{\circ}, U=1955.6(5) \AA^{3}, T=100.01$, space group $\mathrm{P} 21 / \mathrm{c}, Z=2, \mu(\mathrm{MoK} \alpha)=3.894,20578$ reflections measured, 5826 unique $\left(R_{\text {int }}=0.0341\right)$ which were used in all calculations. GOF $=$ $1.100, R(I \geq 2 \sigma(I))=0.0272, w R\left(F_{2}\right)=0.0640$ (all data). CCDC 1523244.

$\left(\mathrm{Pr}_{4} \mathrm{~N}\right)_{2}\left[\mathrm{PtBr}_{6}\right] \cdot \mathrm{TCP} \cdot 2 \mathrm{CH}_{2} \mathrm{Cl}_{2}$. Yellow blocks were prepared by diffusion of hexane into dichloromethane solution containing $28 \mathrm{mg}(0.027 \mathrm{mmol})$ of $\left(\operatorname{Pr}_{4} \mathrm{~N}\right)_{2}\left[\mathrm{PtBr}_{6}\right]$ and $8 \mathrm{mg}(0.044$ $\mathrm{mmol}$ ) of TCP at $-75^{\circ} \mathrm{C}$. Removal of these co-crystals from the mother liquor resulted in their fast decomposition, probably due to loosing of dichloromethane solvate molecules. Crystal data: $\mathrm{C}_{34} \mathrm{H}_{60} \mathrm{Br}_{6} \mathrm{~N}_{8}$ Pt. $\mathrm{M}=1397.25$, monoclinic, $a=9.729(3) \AA, \quad b=10.032(3) \AA ⿻$, $c=25.941(8) \AA$, $\left.\beta=\mathrm{v}^{\circ}, U=2509.9(13)\right) \AA^{3}, T=100.01$, space group $\mathrm{P} 21 / \mathrm{n}, Z=2, \mu(\mathrm{MoK} \alpha)=7.817,29545$ 
reflections measured, 7514 unique $\left(R_{\text {int }}=0.0879\right)$ which were used in all calculations. GOF $=$ 0.996, $R(I \geq 2 \sigma(I))=0.0505, w R\left(F_{2}\right)=0.0987$ (all data). CCDC 1523247 .

$\left(\mathrm{Bu}_{4} \mathrm{~N}\right)_{2}\left[\mathrm{PtBr}_{6}\right] \cdot T C P$. Brown-red blocks were prepared by diffusion of hexane into dichloromethane solution containing $60 \mathrm{mg}(0.051 \mathrm{mmol})$ of $\left(\mathrm{Bu}_{4} \mathrm{~N}\right)_{2}\left[\mathrm{PtBr}_{6}\right]$ and $9 \mathrm{mg}(0.050$ mmol) of TCP at $-75^{\circ} \mathrm{C}$. Analysis: Calc. for $\mathrm{C}_{40} \mathrm{H}_{72} \mathrm{Br}_{6} \mathrm{~N}_{8} \mathrm{Pt}, \%$ : C, 35.86; H, 5.42; N, 8.36. Found, \%: C, 36.03; H, 5.30; N, 8.29. Crystal data: $\mathrm{C}_{40} \mathrm{H}_{72} \mathrm{Br}_{6} \mathrm{~N}_{8} \mathrm{Pt} . \mathrm{M}=1339.54$, triclinic, $a=$

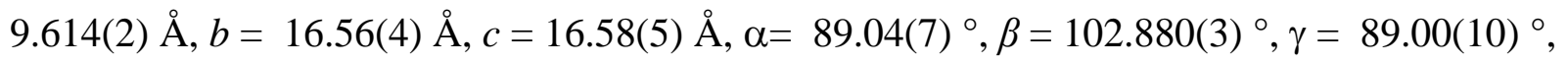
$U=2631(10) \AA^{3}, T=100.01$, space group $\mathrm{P}-1, Z=2, \mu(\mathrm{MoK} \alpha)=7.254,38967$ reflections measured, 15167 unique $\left(R_{\text {int }}=0.0758\right)$ which were used in all calculations. GOF $=1.362, R(I \geq$ $2 \sigma(I))=0.0864, w R\left(F_{2}\right)=0.2464$ (all data). CCDC 1523245.

$\left(\mathrm{Bu}_{4} \mathrm{~N}\right)_{2}\left[\mathrm{Pt}_{2} \mathrm{Br} r_{6}\right] \cdot \mathrm{TCP} \cdot 2 \mathrm{CH}_{2} \mathrm{Cl}_{2}$. Crystals were prepared by diffusion of hexane into dichloromethane solution containing $68 \mathrm{mg}(0.050 \mathrm{mmol})$ of the platinum(II) salt and $9 \mathrm{mg}$ (0.0.050 mmol) of TCP at $-30^{\circ} \mathrm{C}$. Crystal data. $\mathrm{C}_{21} \mathrm{H}_{38} \mathrm{Br}_{3} \mathrm{Cl}_{2} \mathrm{~N}_{4} \mathrm{Pt} . \mathrm{M}=852.27$, triclinic, $a=$ 9.21(4) $\AA, b=9.49(4) \AA, c=16.70(7) \AA, \alpha=86.24(18)^{\circ}, \beta=75.6(2)^{\circ}, \gamma=79.09(12)^{\circ}$, $U=1389(10) \AA^{3}, T=100.01$, space group $\mathrm{P}-1, Z=2, \mu(\mathrm{MoK} \alpha)=9.578,20108$ reflections measured, 8554 unique $\left(R_{\text {int }}=0.0758\right)$ which were used in all calculations. GOF $=1.068, R(I \geq$ $2 \sigma(I))=0.0743, w R\left(F_{2}\right)=0.2291$ (all data). CCDC 1523246.

$\left(\mathrm{Pr}_{4} \mathrm{~N}\right)\left[\mathrm{CuBr} r_{2}\right] \cdot T C P$. Crystalline material was prepared by diffusion of hexane into $5 \mathrm{~mL}$ of dichloromethane solution containing $82 \mathrm{mg}(0.20 \mathrm{mmol})$ of $\left(\mathrm{Pr}_{4} \mathrm{~N}\right)\left[\mathrm{CuBr}_{2}\right]$ and $36 \mathrm{mg}(0.20$ $\mathrm{mmol})$ of TCP at $-30^{\circ} \mathrm{C}$. The pale yellow plates of $\left(\mathrm{Pr}_{4} \mathrm{~N}\right)[\mathrm{CuBr} 2] \cdot \mathrm{TCP}$ precipitated from this solution were contaminated by the dark blocks (probably, products of oxidation of copper(I) bromide). Crystal data: $\mathrm{C}_{20} \mathrm{H}_{28} \mathrm{Br}_{2} \mathrm{Cu} \mathrm{N}_{7} . \mathrm{M}=589.85$, monoclinic, $a=13.089(5) \AA, b=10.245(3)$ $\left.\AA, c=19.133(6) \AA, \beta=95.043(9){ }^{\circ}, U=2555.8(14)\right) \AA^{3}, T=100.01$, space group $\mathrm{P} 2{ }_{1} / \mathrm{n}, Z=4$, 
$\mu(\mathrm{MoK} \alpha)=4.001,26079$ reflections measured, 7597 unique $\left(R_{\text {int }}=0.0609\right)$ which were used in all calculations. GOF $=0.991, R(I \geq 2 \sigma(I))=0.0482, w R\left(F_{2}\right)=0.1111$ (all data). CCDC 1523248 .

Computations: Quantum-mechanical calculations were carried out using the Gaussian 09 suite of programs.[27] Geometries of TCP molecule, $\left[\mathrm{M}_{1} \mathrm{X}_{n}\right]^{\mathrm{m}-}$. anions and $\left[\mathrm{M}_{1} \mathrm{X}_{\mathrm{n}}\right]^{\mathrm{m}-}$.TCP associates in the gas phase via DFT calculations with M06-2X functional and def-TZVPP basis set.[28] For intermolecular complexes, this method provides accurate results at reasonable computational cost.[20, 29] Results of the computations using $\omega$ B97X-D functional or ab initio MP2 method were consistent with the data obtained from the M06-2X/def-TZVPP calculations.

Geometry optimizations were carried out without constraints using the default convergence criteria for Gaussian 09. The absence of the imaginary frequencies confirmed that the optimized structures represent true minima. The energies of interaction were determined by subtracting the sum of the energies of isolated TCP and $\left[\mathrm{M}_{1} \mathrm{X}_{\mathrm{n}}\right]^{\mathrm{m}-}$ species from the energy of the $\left[\mathrm{M}_{1} \mathrm{X}_{\mathrm{n}}\right]^{\mathrm{m}-} \cdot \mathrm{TCP}$ complexes and adding basis set superposition error (BSSE): $\Delta \mathrm{E}=\mathrm{E}_{\mathrm{C}}-\left[\mathrm{E}_{\mathrm{TCP}}+\mathrm{E}_{\mathrm{ML}}\right]+\mathrm{BSSE}$, where $\mathrm{E}_{\mathrm{C}}, \mathrm{E}_{\mathrm{TCP}}$ and $\mathrm{E}_{\mathrm{ML}}$ are sums of the electronic and zero-point energies of the complex, acceptor and anion, respectively. The BSSE values were determined via the counterpoise method. [30] Zero-point energies (ZPE) and thermal corrections were taken from unscaled vibrational frequencies. Energies and atomic coordinates of the calculated $\left[\mathrm{M}_{1} \mathrm{X}_{\mathrm{n}}\right]^{\mathrm{m}-} \cdot \mathrm{TCP}$ complexes are listed in the Supporting Information. Frontier orbital shapes were evaluated at 0.02 isovalues and electrostatic potentials were calculated on the 0.0004 electrons bohr $^{-3}$ molecular surfaces (the ESP surface of TCP calculated at 0.002 isovalue is similar and show the maximum positive potential of $67.1 \mathrm{kcal} \mathrm{mol}^{-1}$ over the center of the aromatic ring). Amount of charge transfer was determined using NBO via the Natural Population Analysis phase of Natural Bond Orbital (NBO) analysis implemented in the Gaussian 09 suite of programs.[31] 
Supporting Information. ORTEP diagrams showing numbering of the contact atoms for all Xray structures, energies and atomic coordinates of the calculated complexes.

Acknowledgements. We thank J.-J. Lu and C. L. Stern for the assistance with the X-ray crystallographic analysis, and the National Science Foundation (grants CHE-1112126 and CHE1607746) and R. A. Welch Foundation for the financial support of this work.

\section{References and Notes.}

1. (a) Quinonero, D.; Garau, C.; Rotger, C.; Frontera, A.; Ballester, P. Costa, A.; Deya, P. M. Angew. Chem. Int. Ed., 2002, 41, 3389. (b) Mascal, M.; Armstrong, A.; Bartberger, M.D. J. Am. Chem. Soc. 2002, 124, 6274. (c) Quiñonero, D.; Garau, C.; Frontera, A.; Ballester, P.; Costa, A.; Deyà, P. M. Chem. Phys. Lett. 2002, 359, 486. d) I. Alkorta, I. Rozas, J. Elguero, J. Am. Chem. Soc. 2002, 124, 8593.

2. Schneider, H.-J.; Werner, F.; Blatter, T. J. Phys. Org. Chem. 1993, 6, 590.

3. Demeshko, S.; Dechert, S.; Meyer, F. J. Am. Chem. Soc. 2004, 126, 4508.

4. Rosokha, Y. S.; Lindeman, S. V.; Rosokha, S. V.; Kochi, J. K. Angew. Chem., Int. Ed., 2004, 43, 4650 .

5. Wang, D.-X.; Wang, M.-X. J. Am. Chem. Soc. 2013, 135, 892.

6. Berryman, O.B.; Bryantsev, V.S.; Stay, D.P.; Johnson, D.W., Hay, B.P. J. Am. Chem. Soc. 2007, 129, 48.

7. (a) Frontera, A.; Gamez, P.; Mascal, M.; Mooibroek, T. J.; Reedijk, J. Angew. Chem. Int. Ed. 2011, 50, 9564. (b) Chifotides, H. T.; Dunbar, K. R. Acc. Chem. Res., 2013, 46, 894. (c) Giese, M.; Albrecht, M.; Rissanen, K. Chem. Revs. 2015, 115, 8867-8895 
8. (a) Estarellas, C.; Frontera, A.; Quiñonero, D.; Deyà, P.M. Angew. Chem., Int. Ed., 2011, 50, 415. (b) Giese, M.; Albrecht, M.; Rissanen, K. Chem. Comm. 2016, 52, 1778. (c) Lucas, X.; Bauza, A.; Frontera, A.; Quinonero, D. Chem. Sci. 2016, 7, 1038.

9. Schottel, B.L.; Chifotides, H.T.; Dunbar, K.R. Chem. Soc. Rev. 2008, 37, 68.

10. Han, B.; Lu, J. J.; Kochi, J. K. Cryst. Grow. Des. 2008, 8, 1327.

11. Podgajny, R.; Pinkowicz, D.; Czarnecki, B.; Kozieł, M.; Chorąży, S.; Wis, M.; Nitek, W.; Rams, M.; Sieklucka, B. Cryst. Grow. Des. 2014, 14, 4030.

12. (a) Lu, J. J.; Kochi, J. K. Cryst. Grow. Des. 2009, 9, 291. (b) Liu, J.-J.; Guan, Y.-F.; Jiao, C.; Lin, M.-J. Huang,.Dai, W.-X. Dalton Trans. 2015, 5957. (c) Gural'skiy, I. A.; Solntsev, P. V.; Krautscheid, H.; Domasevitch, K. V. Chem. Comm. 2006, 4808. (d) Wan, C.-Q.; Li, G.S.; Chen, X.-D.; Mak, T. C. W. Cryst. Grow. Des. 2008, 8, 3897.

13. Bauza, A.; Mooibroek, T. J.; Frontera, A. CrystEngComm, 2016, 18, 10.

14. (a) Giese, M.; Albrecht, M.; Ivanova, G.; Valkonen, A.; Rissanen, K. Supramol. Chem. 2012, 24, 48. (b) Wang, D.-X.; Wang, M.-X.; J. Am. Chem. Soc. 2013, 135, 892. (c) Kim, D. Y.; Singh, N. J.; Kim, K. S. J. Chem. Theory Comput. 2008, 4, 1401.

15. Estarellas, C.; Quinonero, D.; Deya, P. M.; Frontera, A. ChemPhysChem, 2013, 14, 145.

16. Bondi, A. J. Phys. Chem. 1964, 68, 441.

17. Bauzá, A.; Mooibroek, T. J.; Frontera, A. ChemPhysChem, 2015, 16, 2496.

18. Wang, H.; Wang, W.; Jin, W.J. Chem. Revs., 2016, 116, 5072.

19. Rosokha, S. V.; Kochi, J. K. in: Halogen Bonding: Fundamentals and Applications. Structure and Bonding, 2008, 126, 137.

20. Foroutan-Nejad, C.; Badri, Z.; Marek, R. Phys. Chem. Chem. Phys. 2015, 17, 30670. 
21. (a) R.S. Mulliken, W.B. Person, Molecular Complexes, Wiley, N.Y. 1969. (b) Rosokha, S. V.; Dibrov, S.M.; Rosokha, T.Y.; Kochi, J. K. Photochem. Photobiol. Sci., 2006, 5, 914. (c) Sun, D.; Rosokha, S. V.; Kochi, J. K. J. Phys. Chem. B, 2007, 111, 6655.

22. (a) Asplund, M.; Jagner, S.; Nilsson, M. Acta Chem. Scand, A, 1983, A37, 57. (b) Rosokha, S. V.; Lu, J. J.; Rosokha, T. Y.; Kochi, J. K. Chem. Commun., 2007, 3383.

23. Livingstone, S. E. Synthesis in Inorganic and Metal-Organic Chemistry, 1971, 1, 1.

24. Sharutin, V.V.; Senchurin, V.S.; Sharutina, O.K.; Somov, N.V.; Gushchin, A.V. Russ. J. Coord. Chem., 2011, 37, 854.

25. (a) SAINT, Program for Area Detector Absorption Correction; Siemens Analytical X-Ray Instruments Inc.: Madison, WI, 1994-1996. (b) Sheldrick, G. M. SADABS, Program for Siemens Area Detector Absorption Correction; University of Gottingen: Gottingen, Germany, 1996.(c) Sheldrick, G. M. SHELXS-97, A Program for Crystal Structure Solution; University of Gottingen: Gottingen, Germany, 1997

26. O.V. Dolomanov, L.J. Bourhis, R.J. Gildea, J.A.K. Howard, H J. Puschmann, Appl. Cryst. 2009, 42, 339-341.

27. Frisch, M. J.; Trucks, G. W.; Schlegel, H. B.; Scuseria, G. E.; Robb M. A.; Cheeseman, J. R.; Scalman Frisch, M. J.; Trucks, G. W.; Schlegel, H. B.; Scuseria, G. E.; Robb M. A.; Cheeseman, J. R.; Scalmani, G.; Barone, V.; Mennucci, B.; Petersson, G. A., et al. Gaussian 09, Revision C.01, Gaussian, Inc., Wallingford CT, 2009.

28. Zhao, Y.; Truhlar, D.G. Theor. Chem. Acc., 2008, 120, 215.

29. Rosokha, S. V.; Stern, C. L.; Ritzert, J.T. Chem.- Eur. J. 2013, 19, 8774.

30. Boys, S. F.; ; Bernardi, F. Mol. Phys., 1970, 19, 553. 
31. (a) NBO Version 3.1, E. D. Glendening, A. E. Reed, J. E. Carpenter, and F. Weinhold. (b) F. Weinhold and C.R. Landis, Discovering Chemistry with Natural Bond Orbitals, Wiley, Hoboken, NJ, 2012. 